http://dx.doi.org/10.12775/szhf.2020.018

JoAnNa Szalacha-JaRmuŻEK

Nicolaus Copernicus University in ToRuń

E-MAIL: JOANNA.SZALACHA@UMK.PL

ORCID: 0000-0001-6445-8385

Krzysztof Pietrowicz

Nicolaus Copernicus University in ToRuń

E-MAIL: KRZYSZTOF.PIETROWICZ@UMK.PL

ORCID: 0000-0002-0596-4672

\title{
Going Beyond the Dichotomy Problems of Contemporary Sociology in the Context of the Proposals by Jerzy Loś $^{*}$
}

\section{Introduction}

In this article we try to show why a certain element of Jerzy Łośs philosophical-logical considerations, which are now of historical interest, may be interesting for contemporary sociologists (or, more broadly, representatives

* The authors would like to extend their gratitude to Tomasz Jarmużek (Nicolaus Copernicus University in Toruń) and Jacek Malinowski (Polish Academy of Sciences) for their consultations on logic, especially on the significance of the realisation operator. 
of the social sciences). The article is, therefore, oriented towards both the past and the present.

The following research questions are the starting point for our deliberations: (1) How can contemporary social researchers sensibly make use of philosophical perspectives from several decades ago? (2) What is the relationship between philosophy and social sciences, sociology in particular, today? (3) Do sociologists take advantage of the achievements of philosophical logic, including the ideas of the logician Jerzy Łoś? In the three subsequent parts of the article, we will address these questions by sketching the context of collaboration between sociologists and philosophers and highlighting the benefits of using the works of Jerzy Łoś.

\section{Contemporary Sociology Versus the Classics, Sociology Versus Philosophy}

Our paper does not pertain to the history of ideas. While appreciating the importance of purely historical considerations, in this paper, we would like to draw attention to the ongoing dispute in sociology over how to treat the classics, ${ }^{1}$ i.e., whether to treat tradition as an important point of reference for contemporary research or as a closed chapter that may be worth knowing about but that is no longer useful. On the one hand are proponents of forgetting the past and being fully oriented towards the present in the spirit of natural sciences and on the other are researchers who view the social sciences as a dialogue with tradition. ${ }^{2}$ There are researchers even today who live by

1 Krzysztof Pietrowicz, "Dlaczego klasycy? Krótkie rozważania na marginesie lektury C. Wrighta Millsa”, in: Wyobrażone, przeżyte i przedstawione. Ksiega jubileuszowa dla profesora Janusza Muchy, eds. Łukasz Krzyżowski, Katarzyna Leszczyńska, Maria Szmeja (Kraków: Zakład Wydawniczy Nomos, 2019).

2 Arthur L. Stinchcombe, "Should Sociologists Forget Their Mothers and Fathers?", American Sociologist 17 (1982): 2-11. 
Alfred Whitehead's well-known phrase, "A science which hesitates to forget its founders is lost."

At the beginning of the $21^{\text {st }}$ century, Ulrich Beck was prominent as a radical advocate of such a stance. He described the relationship between the classics of social thought and the challenges of today: "There are constant attempts to rediscover Weber for the $21^{\text {st }}$ century. There is an ongoing struggle (since Marx or Durkheim have assumptions for the first modernity in the background), to generalise them, i.e., to behave as if they were independent of the context. But we can see that this cannot be done. The classics of science that we have inherited are becoming an obstacle in the attempts to properly capture a quite ordinary reality." 4 There are also those who preach the opposite. ${ }^{5}$

Most sociologists appear to opt for a pragmatic path in line with the reasoning proposed by Stefan Nowak. Starting with the differences between natural sciences and sociology, he claimed that after World War II, sociology saw the shaping of the "ideal of the continuation of the theoretical thought of the classics from the perspective of the methodology of contemporary sociology. [...] A characteristic feature of what could be called a follow-up analysis is the attempt at a strictly substantive approach to the works of the classics of sociology. Such an approach should be both kind and distrustful. Here, kindness means the desire to bring out everything that, in the light of our contemporary standards, seems to deserve attention, from a given work, if only as a source of inspiration for our own reflections in this field. Distrust, in turn, means an attitude of not taking anything on trust without clearly realising its theoretical sense and the substantive validity of a given author's proposal". ${ }^{6}$ Such an approach can be considered as a proposal to use the classics in a way that is similar to referring to contemporary authors; a possible difference lies in greater leniency towards the classics.

3 Alfred N. Whitehead, The Organization of Thought: Educational and Scientific (London: Williams and Norgate, 1917), 115.

4 Ulrich Beck, "Wiemy coraz mniej. Ulrich Beck w rozmowie ze Sławomirem Sierakowskim”, Krytyka Polityczna 3 (2003): 211.

5 See Paul S. Adler, "A Social Science Which Forgets its Founders is Lost", in: The Oxford Handbook of Sociology and Organization Studies: Classical Foundations, ed. Paul S. Adler (Oxford University Press, 2009).

6 Stefan Nowak, "Wstęp do wydania polskiego", in: Georg Simmel, Socjologia (Warszawa: PWN, 1975), XIII. 
Now, let us move on to the second question. Put simply, the contemporary relationship between philosophy and sociology cannot be considered particularly strong. Returning to the institutionalisation of sociology, i.e., to the $19^{\text {th }}$ century and the beginning of the $20^{\text {th }}$ century, we can easily see the interpenetration of the two disciplines. It can be said that the founding fathers of sociology were also concerned with social philosophy or were, at least, very strongly inspired by their philosophical tradition. In Polish sociology, the case of Florian Znaniecki (the founding father of Polish sociology), who began with strictly philosophical considerations and subsequently moved on to sociology, is particularly symptomatic.

At the beginning of the $21^{\text {st }}$ century, such relations were considerably more limited. Certainly, contemporary quantitative sociology, which focuses primarily on the method and attempts to explain the cause and effect of specific phenomena, has abandoned its philosophical inspirations. Of course, one can move towards a qualitative approach (humanistic, more in-depth) and show, for instance, Michel Foucault's influence on research on social supervision and control, the relationship between the works of Zygmunt Bauman and postmodern philosophers or the clear philosophical inspirations of Bruno Latour's analyses (although Latour is also a philosopher himself). All these are however the examples of quite specific sections of contemporary sociology. Philosophers are mostly treated as providers of metaphors that later inspire sociologists. Such inspiration will not, in principle, refer to logic or analytical philosophy. This has a significant connection with the tension that has persisted in sociology since its very inception but is particularly evident today. In the next section, we will discuss this tension in detail.

\section{Between the Formalisation and the Immeasurable}

One of the unresolved problems of the social sciences is a clear distinction between quantitative and qualitative researchers. The former seeks to explain social phenomena much like how natural phenomena are explained. Thus, there is an emphasis on the formalisation - searching for cause-and-effect relationships and making repetitive measurements - and the mathematisation of 
social reality. Qualitatively oriented researchers focus on the understanding, local description and interpretation of the world of meanings or the reconstruction of collective ways of perceiving the world. Researchers who adopt a qualitative approach tend to reject the possibility of drawing on natural sciences, pointing out the difference between the subjects of research, which is characterised by reflectiveness. Borrowing Florian Znaniecki's phrasing, it can be said that the "humanistic coefficient" and, thus, the ability to take into account how social reality is perceived by its participants is instrumental here. The distinction outlined above is usually presented in a methodological context and combined with the acceptance of certain paradigms by social researchers. ${ }^{7}$ This division can also be presented as one of the dichotomous thought structures that constitute contemporary sociology while being, at the same time, a developmental barrier to the discipline. In other words, the division into quality- and quantity-oriented researchers reflects the opposition between subjectivity and objectivity. ${ }^{8}$

An analysis of the contemporary philosophical inspirations in sociology will reveal that they refer primarily to quality-oriented researchers. Quantityoriented researchers, who place emphasis on formalisation, do not generally refer to logical or philosophical inspirations and predominantly apply readymade tools that, in some cases, have their roots in the natural sciences. This has not always been the case; it is worth mentioning the work of Polish philosopher Klemens Szaniawski, who tried to combine the tradition of the Lvov-Warsaw school with sociology. ${ }^{9}$ Such inspirations, however, have not been widely received.

Although mixed methods that combine a quantitative and qualitative perspective have caught the attention of sociologists since the beginning of the $21^{\text {st }}$ century, ${ }^{10}$ this, in practice, usually means accepting the dominance of

${ }^{7}$ John W. Creswell, Research Design: Qualitative, Quantitative and Mixed Methods Approaches (Thousand Oaks-London-New Delhi: Sage Publications, 2014).

8 More on the meaning of this type of dichotomy: Radosław Sojak, The Anthropological Paradox: The Sociology of Knowledge as Perspective of the General Theory of Society (Berlin: Peter Lang, 2018).

9 See a number of texts in: Klemens Szaniawski, O nauce, rozumowaniu $i$ wartościach. Pisma wybrane (Warszawa: Wydawnictwo Naukowe PWN, 1994).

${ }_{10}$ Creswell, Research Design. 
one of these approaches and complementing it with the other. The actual synthesis of the quantitative (mathematicised, formalisation oriented, objectivistic) and quantitative (taking account of the humanistic coefficient, subjectivistic) approaches remains an unresolved problem in the social sciences. The key question in this context is how it can be done? Here, in our opinion, the concept developed by Jerzy Łoś can help.

\section{Jerzy Łošs Logic and Its Potential for the Social Sciences}

In this section, we will discuss Jerzy Łošs logic and how it can be applied in sociological analyses. It should be stated at the beginning that, in accordance with the overview of the relationship between philosophy and sociology presented here, we will consider certain elements of Łośs scientific output as a source of inspiration.

The proposal presented here is slightly different from the cases of "transitions" between philosophical and sociological analyses in the context of the qualitative perspective discussed earlier. In those cases, philosophers wrote about social reality, which created a framework for sociological research or inspired them in the form of new concepts. Łoś, on the other hand, created his logic with the natural sciences in mind. He was interested in the parameter of time, the extent to which it can be applied and how it can be accounted for in the reasoning engaged in using logic. The logic he proposed, which will be described herein, was supposed to be applied to the natural sciences and provide the possibility of embedding physical processes with the parameter of time or space within the categories of logic. It was certainly not his intention to create a logic for the social sciences. The typical social problems philosophers took interest in (such as power, conflict, human relations, and so on) were not a point of reference for Łoś.

* This fragment develops the theses that have been formulated earlier in the paper: Jacek Malinowski, Krzysztof Pietrowicz, Joanna Szalacha-Jarmużek, "Logic of social ontology and Łośs operator”, Logic and Logical Philosophy 29 (2020): 239-258. 
In reality, however, the logic proposed by Łoś was used in philosophical analyses of such problems as time or modality more often than strictly in natural sciences. ${ }^{11}$

The works of Łoś, i.e., the two articles from 1947 and 1948, referred to temporal logic and epistemic logic, ${ }^{12}$ and substantial evidence is available indicating that they were ground-breaking works that set new directions in logic itself. ${ }^{13}$ Unfortunately, as very often was the case in various branches of science in non-English-speaking circles, the works of Łoś, published in Polish (despite their reviews and discussions being published in English), were quickly forgotten by Western philosophy and formal sciences. The lack of institutional support and obvious difficulties in communicating across borders built a barrier that made it impossible to promote his works or consolidate the position of his findings within the Western scientific community.

The breakthrough madeby $Ł o s ́$ was the introduction of a grammatical construction that facilitated a demonstration of the relationship between a statement and its context. This construction was called the realisation operator. Łoś suggested using the letter " $U$ " as a symbol of the realisation operator. However, the notation with the letter " $R$ ", proposed by Nicholas Rescher, is more common today. ${ }^{14}$ It is worth emphasising that the fact that a different notation for the realisation operator is used nowadays than the one proposed by the author himself illustrates the problems faced by the representatives

11 See Tomasz Jarmużek, Andrzej Pietruszczak, "Completeness of Minimal Positional Calculus", Logic and Logical Philosophy 13 (2004): 147-162; Tomasz Jarmużek, "Minimal Logical Systems with R-operator: Their Metalogical Properties and Ways of Extensions", in: Perspectives on Universal Logic, eds. J. Bézieau, A. Costa-Leite (Monza: Polimetrica International Scientific Publisher, 2007), 319-333; Tomasz Jarmużek, On the Sea Battle Tomorrow That May Not Happen. A Logical and Philosophical Analysis of the Master Argument (Berlin-Warsaw: Peter Lang, 2018); Tomasz Jarmużek, Marcin Tkaczyk, "Expressive Power of the Positional Operator R: A Case Study in Modal Logic and Modal Philosophy", Ruch Filozoficzny (Philosophical Movement) LXXV, 2 (2019): 91-107.

12 Jerzy Łoś, "Podstawy analizy metodologicznej kanonów Milla", Annales Universitatis Mariae Curie-Skłodowska, 2.5. F (1947): 269-301; Jerzy Łoś, "Logiki wielowartościowe a formalizacja funkcji intensjonalnych”, Kwartalnik Filozoficzny XVII, 1-2 (1948): 59-78.

13 Tomasz Jarmużek, Marcin Tkaczyk, Normalne logiki pozycyjne (Lublin: Towarzystwo Naukowe KUL, 2015).

14 Ibidem, 31-32. 
of non-English-speaking sciences in conveying their findings and solutions (at least in the past) to the wider audience of the scientific world.

So, what is the essence of Jerzy Łośs idea? In his work Logiki wielowartościowe a formalizacja funkcji intensjonalnych (Multi-valued logic and formalisation of intensional functions), ${ }^{15}$ he proposed that the realisation operator should be used to model the knowledge of the subject. The operator proposed by Łoś creates new clauses by combining names with clauses. Clause $R_{a}(p)$ means that the individual $a$ has a conviction or assumes/knows that $p$. However, sentences that are within the reach of the $\mathrm{R}$-operator can be interpreted and understood in many other ways. The difference lies in how the denotation of the notation $a$ is understood, which is always the context for clause $p$, in which $p$ can be true, be a part of a set of beliefs and assumptions, and so on. Generally speaking, $a$ can appear as a context of time and space but also as an epistemic context, which refers to the mind of acting individuals. ${ }^{16}$

Łoś's realisation operator is an extremely flexible tool that allows various statements to be placed in relation to their context. The expression $R_{a}(p)$ should be understood as a relation between $a$ and $p$, wherein the clause written as $p$ is in the context defined as $a$ and, therefore, holds a specific property. Thus, the context is the defined "position" in which the clause $p$ is found. Hence, the logics with the $R$-operator are called positional logics. On the other hand, by proposing the first temporal logic, ${ }^{17}$ Łoś proposed a quantification of clauses, moments and time intervals within the range of the $R$-operator. The facts described by the clauses occur at specific

15 Łoś, "Logiki wielowartościowe a formalizacja funkcji intensjonalnych".

16 See Mateusz Klonowski, Krzysztof Krawczyk, "Problem wszechwiedzy logicznej. Krytyka nienormalnych światów i propozycja nowego rozwiązania” (“The problem of logical omniscience. The critique of non-normal worlds and the proposition of new solution"), Filozofia Nauki 27, 1 (2019): 27-48; Marek Lechniak, "Logika epistemiczna Jerzego Łosia a teoria racjonalnego zachowania" ("Epistemic logic of Jerzy Łoś and the theory of rational behaviour"), Roczniki Filozoficzne 26, 1 (1988): 79-91.

17 Łoś, "Logiki wielowartościowe a formalizacja funkcji intensjonalnych"; see also Tomasz Jarmużek, "Rekonstrukcje rozumowania Diodora Kronosa w ontologii czasu punktowego" ("Reconstruction of Diodorus Cronus' argument in frame of ontology of time consisted of points"), Analiza i Egzystencja 3 (2006): 197-215. 
moments or time intervals; hence, we can perform additional operations on the context, moving from a given moment by a certain time interval.

In recent years, research on positional logic has resumed, mainly on the basis of philosophical logic and metatheories of philosophical logics. ${ }^{18}$ However, so far - as we have indicated - the most common method of interpretation is the application of Łośs operator to the context of time (e.g., to a specific time interval as the context of uttering/clause) or subjects of knowledge/convictions. Many new possibilities of putting the realisation operator to use are also available. However, it is possible to apply Łośs positional logic in the analysis of social contexts as well, as has been presented in detail in the work of Malinowski, Pietrowicz and Szalacha-Jarmużek. ${ }^{19}$ The lack of logic dedicated to social issues, with the simultaneous presence and failure to solve the tension between the quantitative and qualitative approaches, helps the positional logic that derives from Łośs ideas gain exceptional attractiveness for sociology.

The possibility of using logic that is dedicated to sociology makes sense if we take into account the development of the entire trend of mathematical sociology or "computational sociology". These sub-disciplines, while trying to combine knowledge and methods that are typical to formal sciences, are based on reasoning conducted according to the principles of logic (classical and non-classical). However, only Łośs positional logic and his realisation operator - providing a chance to grasp social processes in a disciplined way - are suitable for quantitative methods and formal sciences and provide the possibility of capturing the humanistic coefficient that so often escapes sociology when it tries to formalise its reflections on social processes.

As we have stated before, the complexity of social processes manifests itself in at least two dimensions. First is the issue of the number of components subjected to analysis, and second is the presence of the humanistic coefficient, which complicates the distinction between the objective

18 Jarmużek, Pietruszczak, "Completeness of Minimal Positional Calculus”; Cf. Jarmużek, "Minimal Logical Systems with R-operator: Their Metalogical Properties and Ways of Extensions".

19 Malinowski, Pietrowicz, Szalacha-Jarmużek, "Logic of social ontology and Łośs operator"; Tomasz Jarmużek, Aleksander Parol, "On Some Language Extension of Logic MR: A Semantic and Tableau Approach”, Roczniki Filozoficzne 68, 4 (2020). 
and subjective aspects of the examined objects. For instance, consider the process of social group dynamics, which includes individuals (acting people), actions (formation of groups, relations between members, production of own patterns of action, recreation of norms) and individuals' opinions and beliefs regarding the events and processes in which they participated. Various challenges arise in translating this dynamic into a formalised language of science. For instance, it is typical for a sociological description of the world to analyse phenomena that are contained within each other and that are constantly analysed by the participants. The process of the analysis leads to changes in these phenomena.

This problem has been best addressed by Merton in his concept of "selffulfilling prophecy." ${ }^{20}$ The actors' awareness of specific events, reflections on their course and the possibility of consequences can cause a change in their behaviour that, in the long run, modifies the event and directs the social process closer towards the reflection of the actors. This issue, typical of the social world, is also described by the concept of "definition of the situation" formulated by William Thomas. Thomas opines, "If men define situation as real, they are real in their consequences." ${ }^{21}$ Self-reflexiveness in social processes is, therefore, present and well captured by the sociological concept. However, it is problematic to translate it into more formal languages, for example using quantitative variables.

Meanwhile, the realisation operator enables the complexity of the social context to be captured in the language of positional logic. This implies that, on the one hand, the $R$-operator allows clauses that indicate the presence of a subject in a specific context to be created (e.g., places [a specific space], an institution, an organisation, a social group, a position in that group, culture, interaction between individuals, and so on). On the other hand, Łoś's logic allows the issue of the entity's knowledge or convictions concerning this context to be captured in the same statement. Thus, the clause $R_{x_{1}, \ldots, x_{n}}(p)$ reflects the mechanical complexity of the social phenomenon under investigation in the language of logic (this complexity was

20 Robert K. Merton, “The self-fulfilling prophecy”, The Antioch Review 8, 2 (1948): 193210.

21 William I. Thomas, Dorothy Swaine Thomas, The child in America: Behavior problems and programs (New York: Knopf, 1928). 
described earlier in the paper). Variables $x_{1}, \ldots, x_{n}$ refer to the complex ownership of the social world where the event described by the $R$-operator takes place. For instance, one may describe, in this way, the complex context of an event that took place in the context of a social group embedded within a specific organisation that offers certain types of social roles. At the same time, the social specificity of the entity's knowledge and self-awareness is preserved - the specificity of the humanistic coefficient has been captured.

Łośs positional logic and his realisation operator allow - as is presented in detail in the study by Malinowski et al. ${ }^{22}$ - the iteration of contexts to be introduced, i.e., such a nesting thereof as reflects the influence of one context on another. This means that each clause describing a complex social process can be expressed in a specific social context. For instance, the clause $R_{f, c}\left(R_{m, d, c}\left(R_{f}(p) \wedge R_{f, d}(\neg p)\right)\right)$ may be read in the following manner: in company $f$ there is conviction $c$ that manager $m$ who is in charge of division $d$ believes (is convinced $c$ ) that company $f$ as a whole is losing profitability but his division $d$ remains profitable. In the language proposed in Malinowski et al., the nesting of one context within another can be undertaken for a very long chain of sociological categories. In this example, we have an organisation (companies), the social actor in power (manager), an organisational unit (division), the actor's beliefs and an economic factor (profitability), thereby creating a rather complex social context.

An additional aspect that needs to be taken into account when creating logic for the social sciences is the question of the natural uncertainty of the statements used in sociology. In many cases, absolute certainty regarding the credibility of a given sociological thesis is impossible (and, therefore, it is challenging to define it as completely and thoroughly true in terms of the logical value of true or false). However, the problem of the logical value of statements is different in sociology than in the natural sciences. Sociological theses often point to a limited occurrence range of a given phenomenon and strong theses of absolute certainty that a given phenomenon has occurred are relatively rare. Therefore, an important aspect of

22 Malinowski, Pietrowicz, Szalacha-Jarmużek, "Logic of social ontology and Łośs operator". 
formalised language for sociology is the question of the degree to which it is certain that a given event has occurred. The introduction of certainty grading is possible if we accept the following notation: $v_{0}, \ldots, v_{i}, \ldots, v_{m}$, which refers to the order of certainty. Here, $v_{0}$ denotes the event never occurring and $v_{m}$ means that it has occurred for sure. Combining this solution with the R-operator, we obtain the expression $R_{x_{1}, \ldots, x_{n}, v_{i}}(A)$, where $x_{1}, \ldots, x_{n}$ are social contexts where the event described by clause $A$ has occurred with the degree of certainty $v_{i}$. Here, $v_{i}$ may also signify probability; for instance, if in the pre-election survey, candidate John Smith received $x \%$ of all votes, he is likely to be elected Senator of constituency $\mathrm{O}$ with probability $p$. Another example that can be used here is the thesis from Mark Granovetter's classic work The Strength of Weak Ties in which, when studying sociometric networks and information flow (diffusion of knowledge) in them, he states that "whatever is to be diffused can reach a larger number of people, and traverse a greater social distance (i.e., path length) when passed through weak ties rather than strong." ${ }^{23}$

Granovetter's thesis that information is better transmitted through weak ties in social networks shows the social context of the phenomenon (large number of people, large social distance and geographical distance, to some extent) and determines the condition (strength/weakness of ties) in which the information transmission will occur (with some probability). This thesis can also be precisely expressed in the language of positional logic by accommodating the complex contexts containing the parameters of the strength of information flow.

\section{Conclusions}

The possibility of using the ideas that originated decades ago in the philosophy of Jerzy Łoś to solve contemporary sociological dilemmas shows that mutual philosophical and sociological inspirations need not be limited

${ }^{23}$ Mark S. Granovetter, “The Strength of Weak Ties”, American Journal of Sociology 78, 6 (1973): 1366. 
to the use of concepts and metaphors taken out of context; the philosophical tradition may still be alive from the perspective of contemporary sociology and not within the scope of considerations referring to the influence of philosophy classics on the development of social sciences. As we have tried to show, strictly philosophical considerations of historical importance, created for a completely different purpose (for the natural sciences), can be creatively developed in the field of empirical sociology.

Of course, another question that arises is whether the $R$-operator will be used effectively and contribute to connecting a qualitative perspective with the quantitative one. This would probably require the initial concept by Jerzy Łoś to be significantly developed and corrected. We have suggested some of these required modifications in the paper either directly or through references to works on positional logic. However, their implementation and the recommendation of further modifications are tasks for the future.

\section{References}

Adler Paul S. 2009. "A Social Science Which Forgets its Founders is Lost". In: The Oxford Handbook of Sociology and Organization Studies: Classical Foundations, ed. Paul S. Adler, 3-19. Oxford: Oxford University Press.

Beck Ulrich. 2003. "Wiemy coraz mniej. Ulrich Beck w rozmowie ze Sławomirem Sierakowskim". Krytyka Polityczna 3: 208-221.

Creswell John W. 2014. Research Design: Qualitative, Quantitative and Mixed Methods Approaches. Thousand Oaks-London-New Delhi: Sage Publications.

Granovetter Mark S. 1973. "The Strength of Weak Ties". American Journal of Sociology 78, 6: 1360-1380.

Jarmużek Tomasz, Andrzej Pietruszczak. 2004. "Completeness of Minimal Positional Calculus". Logic and Logical Philosophy 13: 147-162.

Jarmużek Tomasz, Marcin Tkaczyk. 2015. Normalne logiki pozycyjne. Lublin: Towarzystwo Naukowe KUL.

Jarmużek Tomasz, Marcin Tkaczyk. 2019. "Expressive Power of the Positional Operator R: A Case Study in Modal Logic and Modal Philosophy". Ruch Filozoficzny (Philosophical Movement) LXXV, 2: 91-107. 
Jarmużek Tomasz, Aleksander Parol. 2020. "On Some Language Extension of Logic MR: A Semantic and Tableau Approach". Roczniki Filozoficzne (Annals of Philosophy) 68, 4: 345-366.

Jarmużek Tomasz. 2006. "Rekonstrukcje rozumowania Diodora Kronosa w ontologii czasu punktowego" ("Reconstruction of Diodorus Cronus' argument in frame of ontology of time consisted of points"). Analiza i Egzystencja 3: 197-215.

Jarmużek Tomasz. 2007. "Minimal Logical Systems with R-operator: Their Metalogical Properties and Ways of Extensions". In: Perspectives on Universal Logic, eds. J. Bézieau, A. Costa-Leite, 319-333. Monza: Polimetrica International Scientific Publisher.

Jarmużek Tomasz. 2018. On the Sea Battle Tomorrow That May Not Happen. A Logical and Philosophical Analysis of the Master Argument. Berlin-Warsaw: Peter Lang.

Klonowski Mateusz, Krzysztof Krawczyk. 2019. "Problem wszechwiedzy logicznej. Krytyka nienormalnych światów i propozycja nowego rozwiązania”. Filozofia Nauki 27, 1: 27-48.

Lechniak Marek. 1988. "Logika epistemiczna Jerzego Łosia a teoria racjonalnego zachowania" ("Epistemic logic of Jerzy Łoś and the theory of rational behaviour"). Roczniki Filozoficzne 26, 1: 79-91.

Łoś Jerzy. 1947. "Podstawy analizy metodologicznej kanonów Milla". Annales Universitatis Mariae Curie-Skłodowska, 2.5. F: 269-301.

Łoś Jerzy. 1948. "Logiki wielowartościowe a formalizacja funkcji intensjonalnych". Kwartalnik Filozoficzny XVII, 1-2: 59-78.

Malinowski Jacek, Krzysztof Pietrowicz, Joanna Szalacha-Jarmużek. 2020. "Logic of Social Ontology and Łošs Operator". Logic and Logical Philosophy 29: 239-258.

Merton Robert K. 1948. "The Self-Fulfilling Prophecy". The Antioch Review 8, 2: $193-210$.

Nowak Stefan. 1975. "Wstęp do wydania polskiego". In: Georg Simmel, Socjologia, IX-XXXI. Warszawa: PWN.

Pietrowicz Krzysztof. 2019. "Dlaczego klasycy? Krótkie rozważania na marginesie lektury C. Wrighta Millsa". In: Wyobrażone, przeżyte i przedstawione. Ksiega jubileuszowa dla profesora Janusza Muchy, eds. Łukasz Krzyżowski, Katarzyna Leszczyńska, Maria Szmeja, 80-93. Kraków: Zakład Wydawniczy Nomos.

Sojak Radosław. 2018. The Anthropological Paradox: The Sociology of Knowledge as Perspective of the General Theory of Society. Berlin: Peter Lang.

Stinchcombe Arthur L. 1982. "Should Sociologists Forget Their Mothers and Fathers?". American Sociologist 17, 2: 2-11.

Szaniawski Klemens. 1994. O nauce, rozumowaniu i wartościach. Pisma wybrane. Warszawa: Wydawnictwo Naukowe PWN.

Thomas William I., Dorothy Swaine Thomas. 1928. The child in America: Behavior problems and programs. New York: Knopf. 
Tkaczyk Marcin, Tomasz Jarmużek. 2019. “Jerzy Łoś Positional Calculus and the Origin of Temporal Logic". Logic and Logical Philosophy 28: 259-276.

Whitehead Alfred North. 1917. The Organization of Thought: Educational and Scientific. London: Williams and Norgate.

\begin{abstract}
The article attempts to show how certain ideas formulated several decades ago by Jerzy Łoś may be useful from the perspective of contemporary sociology. Starting with a reflection on the relations between philosophy and sociology, the authors of the paper address the problem of the concept of the realisation operator and its utility in formalising the social sciences, taking into account the humanistic coefficient and other elements that constitute a qualitative approach in sociology.
\end{abstract}

Keywords: Jerzy Łoś, positional logic, temporal logic, many-valued logic, realisation operator, sociology, humanistic coefficient 